\title{
IMPACT OF CLIMATE CHANGE AND AGRICULTURAL PRACTICES ON IRRIGATION WATER REQUIREMENTS UNDER NILE DELTA CONDITIONS
}

\author{
Atef Swelam* and Samia, M. El-Marsafawy**
}

\begin{abstract}
Agriculture in Egypt consumes about $80 \%$ of the available water resources. With an ever-increasing demand and a relatively fixed supply of fresh water, every drop of water should be treated as a drop of life. Consequently, effective on-farm irrigation management becomes a must. The present study aims to estimate amounts of irrigation water (IW) requirements for crops grown in the Nile Delta Region over three decades (1985-2015). In addition, the impact of weather variability on the irrigation water needs from year to year is assessed using the FAO CROPWAT 8.0 model. Results showed that the mean IW requirements for winter crops ranged between 3,812 $\mathrm{m}^{3} \mathrm{ha}^{-1}$ (kidney beans) and 5,610 $\mathrm{m}^{3}$ $h^{-1}$ (sugar beet). On the other hand, IW requirements for summer crops are much higher with mean values ranging between 5,483 $\mathrm{m}^{3} \mathrm{ha}^{-1}$ (kidney beans) to 25,411 $\mathrm{m}^{3} \mathrm{ha}^{-1}$ (sugarcane). For orchards, the mean amount of IW requirement ranged between $11,728 \mathrm{~m}^{3} \mathrm{ha}^{-1}$ (grapes) to 24,059 $m^{3} . h a^{-1}$ (banana). Variability of IW requirements due to climate variability ranged between $-14 \%$ and $+27 \%$ for winter field crops, between $-6 \%$ and $+17 \%$ for winter vegetable crops, between $-6 \%$ and $+19 \%$ for summer field crops, between $-6 \%$ and $+20 \%$ for summer vegetable crops, and between $-5 \%$ and $+20 \%$ for orchards. Summer cultivation of the same vegetable crops results in an increase in water consumption ranging between 44 and 145\%. The use of new short duration varieties of rice (120 days instead of 150 days) saves about 4,000 $\mathrm{m}^{3} \mathrm{ha}^{-1}$ of irrigation water.
\end{abstract}

Keywords: Nile Delta Region, CROPWAT8.0 model, irrigation water requirement, weather variability

\footnotetext{
* Agricultural Engineering Department, Faculty of Agriculture, University of Zagazig, Currently: International Centre for Agricultural Research in the Dry Areas (ICARDA)

**Soils, Water \& Environment Res. Inst., Agricultural Research Centre, Egypt
} 


\section{INTRODUCTION}

W

ater is a crucial natural resource that is a key development element in all sectors. Given the current climatic uncertainty and changing public policies, competition for water resources is increasing, which makes it a priority for research. The need for accurate crop water requirement estimation for agricultural water management is widely recognized (Tao et al., 2014). Based on meteorological and agronomic data, this paper derives several indices that are deemed relevant variables for determining crop yield, e.g. crop water stress, excess moisture, average soil moisture, etc.

According to ICARDA (2016), sustainable increases in future food supplies must come from increased productivity of both rainfed and irrigated agriculture - producing "more crop per drop". Climate change models predict that northern and southern Africa and West Asia regions will become hotter and drier, which can lead to changes in the seasonal and spatial distribution of precipitation and the increase of occurrence and strength of extreme weather events such as drought.

Schneekloth et al. (2009) indicate that when producers cannot apply water to meet the ET of the crop, they must realize that with typical management practices, yields and returns from the irrigated crop are reduced relative to a fully irrigated crop. To properly manage the water for the greatest return, producers must have an understanding of how crops respond to water, how crop rotations can enhance irrigation management, and how changes in agronomic practices can influence water needs. Molden et al. (2001) report that, when water becomes scarce, water demand management is crucial for an overall water management strategy.

Since Egypt is extremely arid and irrigation water constitutes $80-85 \%$ of the annual available water resources, Egyptian agriculture is essentially fully irrigated. Demands are continuously rising while supplies are mostly fixed, so every drop of water is important. Water is one of the most important inputs to economic development (Allam et al., 2005), and size, type, and location of the economic activity depends on the location, nature, quantity, and quality of the available water resources. Since the Nile Delta Region is characterized by large tracts of rich fertile 
agricultural land, overpopulation, unique and delicate environmental conditions caused by the mixing of drainage and fresh water, unique flora and fauna, and problems associated with low lying areas such as sea water intrusion, good water management of is critical for the ecological balance in this region. In addition, competition between water sectors is increasing and appropriate measures are needed to balance the demand. Consequently, the performance of water delivery systems, particularly irrigation systems, needs to be clearly defined and assessed under these current or expected stressed conditions.

For effective and efficient use of the available water resources, improved irrigation management plays an important role (Sheng-Feng et al., 2001). Kumar et al. (2012) comment that efficient crop water management requires accurate irrigation scheduling that, in turn, requires accurate data on crop water requirements. CROPWAT 8.0 is a decision support tool developed by the United Nations Food and Agriculture Organization (FAO), and the application program aids in the development of irrigation schedules for different management conditions and the calculation of scheme water supplies for various crop patterns. The FAO-CROPWAT8.0 is used to evaluate farmers' irrigation practices and to estimate the crop performance under irrigated conditions.

The objective of this research was to estimate the irrigation water requirements for North Nile Delta crops over the last three decades (19852015) to elaborate the impact of weather variability on crop water requirement and how the requirements change from one year to another.

\section{MATERIALS AND METHODS}

The selected study area is Kafr El-Sheikh Governorate, which located in the Nile Delta Region, that encompasses also Gharbia, Menofya, Dakahleyia, and Damietta Governorates. Kafr El Sheikh is an agricultural governorate, with total cultivated lands of about 253 thousand ha. The study area cropping is dominated by rice, sugarbeets, cotton, and wheat production in addition to aquaculture.

Meteorological data were collected from a weather station located in the Agricultural Research Center, Sakha Station, Kafr El Sheikh Governorate (Altitude: $20 \mathrm{~m}$; Latitude: $31.07^{\circ} \mathrm{N}$, Longitude: $30.57^{\circ} \mathrm{E}$ ). Kafr El-Sheikh 
has a Southern Mediterranean climate condition with daily mean temperature varying between $12.5^{\circ} \mathrm{C}$ in January to $26.4^{\circ} \mathrm{C}$ in July. The mean annual rainfall is about $72 \mathrm{~mm}$. The soil in the study area is clay with good water holding capacity and moderately high soil salinity. Typical soil chemical characteristics are provided in the table $1 \mathrm{a}$ and $\mathrm{b}$ :

Table (1) a: Soil chemical properties of the study area

\begin{tabular}{|c|c|c|c|c|c|c|c|c|c|c|c|c|}
\hline \multirow{2}{*}{$\begin{array}{l}\text { Soil } \\
\text { depth } \\
(\mathrm{cm}) \\
\end{array}$} & \multicolumn{4}{|c|}{ Cations, meq $\mathrm{L}^{-1}$} & \multicolumn{4}{|c|}{ Anions, meq $\mathrm{L}^{-1}$} & \multirow[b]{2}{*}{ SP } & \multirow[b]{2}{*}{$\mathrm{EC}, \mathrm{dS} \mathrm{m}{ }^{-1}$} & \multirow[b]{2}{*}{$\mathrm{pH}$} & \multirow[b]{2}{*}{$\mathrm{CaCO}_{3}$} \\
\hline & $\mathrm{K}+$ & $\mathrm{Na}+$ & $\begin{array}{l}\mathrm{Mg}+ \\
+ \\
\end{array}$ & $\mathrm{Ca}++$ & $\mathrm{SO}_{4-}$ & Cl- & $\mathrm{HCO}_{3-}$ & $\mathrm{CO}_{3}$ & & & & \\
\hline $0-15$ & 3.91 & 21.2 & 3.79 & 11.1 & 5.3 & 30.1 & 4.6 & - & 55.1 & 4.35 & 8.11 & 3.5 \\
\hline $15-30$ & 2.22 & 9.3 & 2.47 & 3.01 & 2.29 & 12.8 & 1.91 & - & 59.1 & 1.89 & 8.19 & 4.2 \\
\hline $30-45$ & 5.12 & 18.7 & 4.98 & 5.2 & 3.89 & 24.2 & 2.91 & - & 57.1 & 3.4 & 8.15 & 3.3 \\
\hline $45-60$ & 4.2 & 20.1 & 3.6 & 6.3 & 2.6 & 27.9 & 3.7 & - & 60.1 & 3.62 & 7.92 & 4.1 \\
\hline
\end{tabular}

Table (1) b: Soil mechanical and hydro-physical characteristics

\begin{tabular}{|c|c|c|c|c|c|c|c|c|c|}
\hline \multirow{2}{*}{$\begin{array}{l}\text { Soil } \\
\text { depth, } \\
(\mathrm{cm})\end{array}$} & \multicolumn{4}{|c|}{ Particle size distribution (\%) } & \multirow[b]{2}{*}{ Texture } & \multirow{2}{*}{$\begin{array}{c}\text { Organic } \\
\text { matter (\%) }\end{array}$} & F.C & W.P & A.W \\
\hline & $\begin{array}{c}\text { Coarse } \\
\text { sand }\end{array}$ & $\begin{array}{l}\text { Fine } \\
\text { sand }\end{array}$ & Silt & Clay & & & \multicolumn{3}{|c|}{$\%$} \\
\hline $0-15$ & 4.1 & 14.6 & 39.8 & 41.6 & Clay & 1.9 & 40.6 & 19.3 & 21.3 \\
\hline $15-30$ & 4.5 & 13.2 & 42.0 & 40.3 & “ & 1.4 & 44.8 & 21.4 & 23.4 \\
\hline $30-45$ & 4.3 & 14.9 & 41.3 & 39.5 & “ & 0.62 & 43.5 & 20.4 & 23.1 \\
\hline $45-60$ & 4.5 & 13.2 & 42.0 & 4.3 & “ & 0.75 & 47.6 & 22.5 & 25.1 \\
\hline
\end{tabular}

\section{Reference evapotranspiration (ET)}

According to Allen et al., 1998, reference evapotranspiration $\left(E T_{o}\right)$ is the rate of evapotranspiration from a large well-watered grass area with height of $10 \mathrm{~cm}$. Figure 1 shows calculated monthly means of daily reference evapotranspiration $\left(E T_{o}\right)$ for Kafr El-Sheikh Governorate during the three decades (1985-2015). ETo was calculated using CROPWAT8.0 and the modified FAO Penman-Monteith equation:

$$
\mathrm{ET}_{0}=\frac{0.408\left(R_{n}-G\right)+\gamma \frac{900}{T+273} u_{2}\left(e_{s}-e_{a}\right)}{\Delta+\gamma\left(1+0.34 u_{2}\right)}
$$


Where $\mathrm{ET}_{\mathrm{o}}$ is the reference evapotranspiration $\left[\mathrm{mm} \mathrm{day}^{-1}\right], R_{n}$ is the net radiation at the crop surface $\left[\mathrm{MJ} \mathrm{m}^{-2}\right.$ day $\left.^{-1}\right], G$ is the soil heat flux density [MJ m ${ }^{-2}$ day $\left.^{-1}\right], T$ is the mean daily air temperature at $2 \mathrm{~m}$ height $\left[{ }^{\circ} \mathrm{C}\right]$, $u_{2}$ is the wind speed at $2 \mathrm{~m}$ height $\left[\mathrm{m} \mathrm{s}^{-1}\right], e_{s}$ is the saturation vapour pressure $[\mathrm{kPa}], e_{a}$ is the actual vapour pressure $[\mathrm{kPa}], e_{s}-e_{a}$ is the saturation vapour pressure deficit $[\mathrm{kPa}], \Delta$ is the slope vapour pressure curve $\left[\mathrm{kPa}^{\circ} \mathrm{C}^{-1}\right]$, and $\gamma$ is the psychrometric constant $\left[\mathrm{kPa}^{\circ} \mathrm{C}^{-1}\right]$.

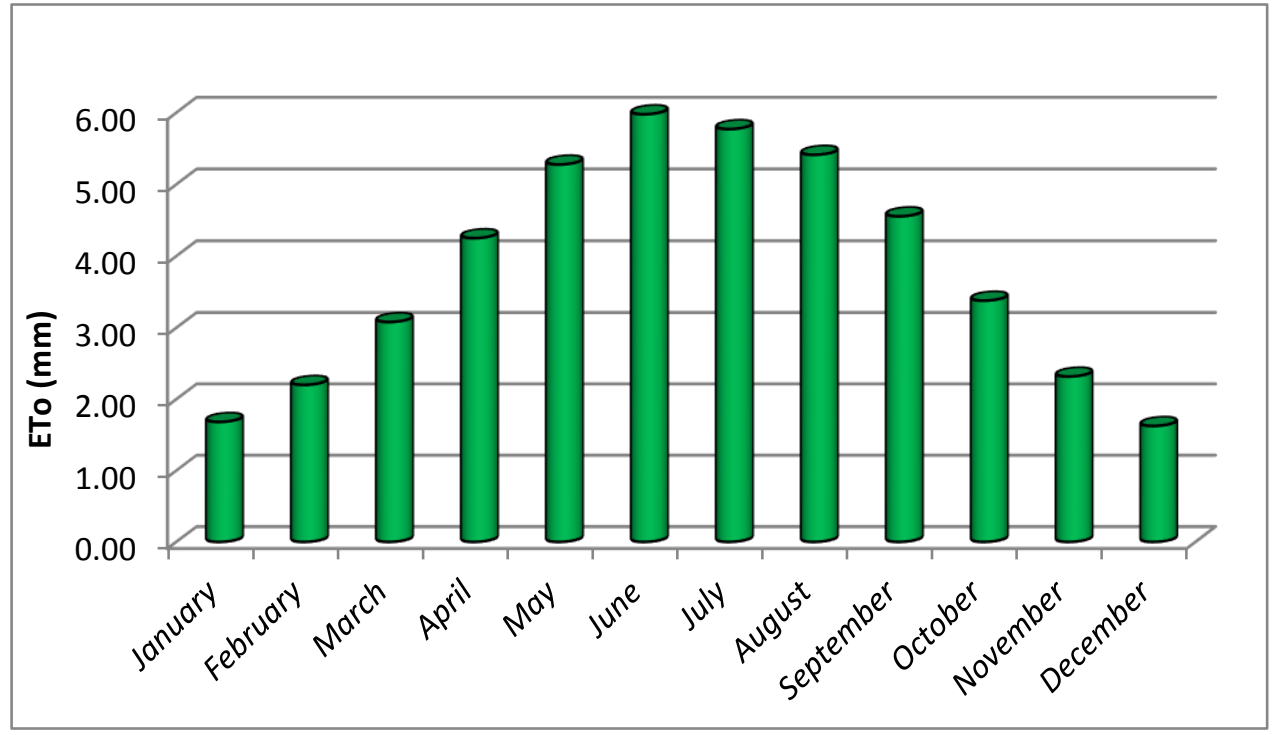

Figure 1: Average monthly reference evapotranspiration (ETo) in Kafr ElSheikh governorate during three decades (1985-2015)

\section{Crop evapotranspiration (ETc)}

Crop evapotranspiration (ETc) is calculated based on the following equation:

$$
E T_{c}=K_{c} \times E T_{o}
$$

Where $E T_{c}$ is the crop evapotranspiration [mm.d $\left.\mathrm{d}^{-1}\right]$ and $K_{c}$ is the crop coefficient [dimensionless]. The detailed data needed by the CROPWAT 8.0 model to calculate crop water consumption in the study are shown in Table 1 for winter crops and Table 2 for orchards. Crop coefficient values $(K c)$ and growth stages were adopted from Allen et al., 1998. The growth stages, dates and Kc for studied crops are shown in Table 2. 
Table 2: Crop coefficient, growth stages, sowing and harvesting dates and season length for crops grown in the Nile Delta Region.

\begin{tabular}{|c|c|c|c|c|c|c|c|c|c|c|}
\hline \multirow[t]{2}{*}{ Crop } & \multicolumn{3}{|c|}{$\begin{array}{c}\text { Crop Coefficient } \\
(\text { Kc })\end{array}$} & \multicolumn{4}{|c|}{$\begin{array}{c}\text { Growth Stages } \\
(\text { day })\end{array}$} & \multirow[t]{2}{*}{$\begin{array}{c}\text { Sowing } \\
\text { Date }\end{array}$} & \multirow[t]{2}{*}{$\begin{array}{c}\text { Harvesting } \\
\text { Date }\end{array}$} & \multirow{2}{*}{$\begin{array}{c}\text { Season } \\
\text { Length } \\
\text { (day) }\end{array}$} \\
\hline & 1 & 2 & 3 & 1 & 2 & 3 & 4 & & & \\
\hline \multicolumn{11}{|l|}{ Winter Field crops } \\
\hline Barley & 0.30 & 1.05 & 0.50 & 30 & 40 & 50 & 30 & 01-Nov & 30-Mar & 150 \\
\hline Faba bean (Dry) & 0.50 & 1.05 & 0.70 & 30 & 40 & 40 & 40 & 15 -Oct & 13-Mar & 150 \\
\hline Garlic & 0.45 & 1.20 & 0.75 & 30 & 40 & 50 & 30 & 01-Oct & $27-\mathrm{Feb}$ & 150 \\
\hline Onion & 0.45 & 1.20 & 0.75 & 30 & 40 & 50 & 30 & 01-Oct & $27-\mathrm{Feb}$ & 150 \\
\hline Sugar beet & 0.35 & 1.20 & 0.70 & 35 & 45 & 50 & 50 & 01-Oct & 29-Mar & 180 \\
\hline Wheat & 0.30 & 1.15 & 0.50 & 30 & 65 & 40 & 30 & $15-\mathrm{Nov}$ & 28-Apr & 165 \\
\hline \multicolumn{11}{|l|}{ Winter vegetable crops } \\
\hline Cabbage & 0.50 & 1.05 & 0.85 & 40 & 50 & 45 & 15 & 01-Sep & 28-Jan & 150 \\
\hline Egg plant & 0.50 & 1.10 & 0.80 & 30 & 45 & 45 & 30 & 01-Oct & 27-Feb & 150 \\
\hline Kidney bean (green) & 0.45 & 1.20 & 0.75 & 30 & 25 & 25 & 10 & 01-Sep & 29-Nov & 90 \\
\hline Pepper & 0.50 & 1.05 & 0.80 & 30 & 45 & 45 & 30 & 01-Sep & 28-Jan & 150 \\
\hline Squash & 0.60 & 1.05 & 0.90 & 25 & 35 & 35 & 25 & 01-Sep & 29-Dec & 120 \\
\hline Tomato & 0.45 & 1.15 & 0.80 & 30 & 45 & 45 & 30 & 01-Sep & 28-Jan & 150 \\
\hline \multicolumn{11}{|l|}{ Summer field crops } \\
\hline Cotton & 0.40 & 1.10 & 0.60 & 30 & 45 & 50 & 55 & 01-Apr & 27-Sep & 180 \\
\hline Maize & 0.30 & 1.20 & 0.75 & 20 & 35 & 35 & 30 & 15-May & 11-Sep & 120 \\
\hline Onion & 0.45 & 1.20 & 0.75 & 30 & 40 & 50 & 30 & 15-Apr & 11-Sep & 150 \\
\hline Rice (short duration varieties) & 1.20 & 1.20 & 1.10 & 30 & $20+20$ & 25 & 25 & 15-May & 12-Aug & 120 \\
\hline Rice (long duration varieties) & 1.20 & 1.20 & 1.10 & 30 & $25+25$ & 35 & 35 & 15-May & 11-Sep & 150 \\
\hline Soybean & 0.40 & 1.15 & 0.60 & 20 & 35 & 40 & 25 & 01-May & 28-Aug & 120 \\
\hline Sugarcane & 0.40 & 1.25 & 0.75 & 30 & 60 & 180 & 95 & $01-\mathrm{Feb}$ & 31-Jan & 365 \\
\hline \multicolumn{11}{|l|}{ Summer vegetable crops } \\
\hline Cabbage & 0.50 & 1.05 & 0.85 & 40 & 50 & 45 & 15 & 01-Apr & 28-Aug & 150 \\
\hline Egg plant & 0.50 & 1.10 & 0.80 & 30 & 45 & 45 & 30 & 01-Mar & 28-Jul & 150 \\
\hline Kidney bean (green) & 0.45 & 1.20 & 0.75 & 30 & 25 & 25 & 10 & 01-Mar & 29-May & 90 \\
\hline Pepper & 0.50 & 1.05 & 0.80 & 30 & 45 & 45 & 30 & 01-Mar & 28-Jul & 150 \\
\hline Squash & 0.60 & 1.05 & 0.90 & 25 & 35 & 35 & 25 & 01-Feb & 31-May & 120 \\
\hline Tomato & 0.45 & 1.15 & 0.80 & 30 & 45 & 45 & 30 & 01-Mar & 28-Jul & 150 \\
\hline
\end{tabular}

\section{Irrigation water requirements (IWR)}

The irrigation efficiency is needed for the determination of irrigation water requirements. The irrigation efficiency is the ratio between water actually consumed by crops and irrigation water applied. According to Jensen (1980) irrigation efficiency for surface irrigation systems is approximately $60 \%$. However, for submerged crops such as rice, an 
irrigation efficiency of 50\% is often used (Dastane, 1972 and Doorenbos and Pruitt, 1977).

\section{Calibration of FAO-CROPWAT8.0 model against field measurement}

Data in Table (3) shows a comparison between crop ET values estimated using four $E T_{o}$ equations and crop coefficients compared to field measured cotton crop $\mathrm{ET}_{\mathrm{c}}$. It is clear from the table that Modified Penman and Penman Monteith formulae performed best at calculating $E T_{c}$ of cotton due to the higher ratios of predicted to measured ETc.

Table (3): Comparison between cotton ET values estimated using different methods (Rayan et. al. (2000))

\begin{tabular}{|l|c|c|c|c|c|c|}
\hline Season & \multicolumn{2}{|c|}{1998} & \multicolumn{2}{c|}{1999} & \multicolumn{2}{c|}{ Average } \\
\hline Methods & $\begin{array}{c}\text { ETc } \\
\mathrm{m}^{3} / \mathrm{fad}\end{array}$ & Ratio & $\begin{array}{c}\text { ETc } \\
\mathrm{m}^{3} / \mathrm{fad}\end{array}$ & Ratio & $\begin{array}{c}\text { ETc } \\
\mathrm{m}^{3} / \mathrm{fad}\end{array}$ & Ratio \\
\hline Modified Penman & 4091 & 0.99 & 4175 & 0.99 & 4133 & 0.99 \\
\hline Penman Monteith & 4166 & 1.00 & 4108 & 0.97 & 4137 & 0.99 \\
\hline Doorenbos-Pruitt & 3556 & 0.86 & 3661 & 0.87 & 3609 & 0.86 \\
\hline Evaporation pan & 3624 & 0.87 & 3580 & 0.85 & 3602 & 0.86 \\
\hline Actual measured ETc & 4150 & & 4217 & & 4184 & \\
\hline
\end{tabular}

Table (4) shows a comparison between ETc values estimated by four ETo equations and $\mathrm{Kc}$ values compared to field measured wheat ETc.

Table (4): Comparison between wheat ET values estimated using different methods (El- Marsafawy et. al. (1998))

\begin{tabular}{|l|c|c|c|c|c|c|}
\hline Season & \multicolumn{2}{|c|}{$1995 / 96$} & \multicolumn{2}{c|}{$1996 / 97$} & \multicolumn{2}{c|}{ Average } \\
\hline Formulae & $\begin{array}{c}\text { ETcrop } \\
\mathrm{Mm}\end{array}$ & Ratio & $\begin{array}{c}\text { ETcrop } \\
\mathrm{mm}\end{array}$ & Ratio & $\begin{array}{c}\text { ETcrop } \\
\mathrm{mm}\end{array}$ & Ratio \\
\hline Penman & 359.3 & 1.11 & 334.8 & 0.99 & 347.1 & 1.05 \\
\hline Penman Monteith & 348.9 & 1.08 & 322.3 & 0.96 & 335.6 & 1.02 \\
\hline Doorenbos- Pruitt & 316.4 & 0.98 & 308.5 & 0.91 & 312.5 & 0.95 \\
\hline Actual measured ET & 323.7 & & 337.5 & & 330.6 & \\
\hline
\end{tabular}




\section{RESULTS AND DISCUSSION}

\section{Winter field and vegetable crops}

Winter field crops grown in Kafr El-Sheikh Governorate include barley, faba bean, garlic, onion, sugar beet and wheat. Winter vegetables include cabbage, eggplant, kidney beans, pepper, squash and tomato. It is noted that these winter vegetables are have also varieties that cultivated in summer as shown 3

Figure 2 shows average variation of irrigation water requirement (IWR) for winter field and vegetable crops over three decades, and percent increase or decrease in comparison to the three-decade average.

Average IWR for winter field crops over three decades were 3968, 4220, $4609,4630,5610$, and $5600 \mathrm{~m}^{3} \mathrm{ha}^{-1}$ for barley, faba bean, garlic, onion, sugarbeet, and wheat, respectively. IWR values for winter vegetables were 4839, 4459, 3812, 5086, 4852, and $5205 \mathrm{~m}^{-3} \mathrm{ha}^{-1}$ for cabbage, eggplant, kidney beans, pepper, squash and tomato, respectively (Figure $3)$.

For the winter crops, years with higher amounts of rainfall required smaller amounts of irrigation water especially during the months of January, February, and March. Clearly, winters that included a higher temperature, lower relative humidity, and increasing wind speed resulted in higher IWR for winter crops by up to $+22 \%$ compared to the calculated 3-decade mean.

Impact of intra-annual variability (from year to year) on IWR for winter crops are presented in Figures 2 and 3. It is observed that IWR decreased during the last five years for all winter crops except kidney beans in 2010 and 2013 (increased by 1\%) and squash in 2015 (increased by 1\%).

The IWR decreased due to increase in the amounts of rainfall over the study region in the last five years (from 2011 to 2015), compared to the average over the study period. Percentage increase in rainfall was $+99 \%$, $+57 \%,+74 \%,+94 \%$ and $+94 \%$ during the five growing seasons within the period 2010/2011 up to 2014/2015.

The largest decrease in IWR for winter field crops was found in the 2011/2012 season due to decrease in maximum temperature, minimum temperature and wind speed by $14.5,21.5$ and $21 \%$, respectively; and an increase in relative humidity and rainfall by 3 and 57\%, respectively. 

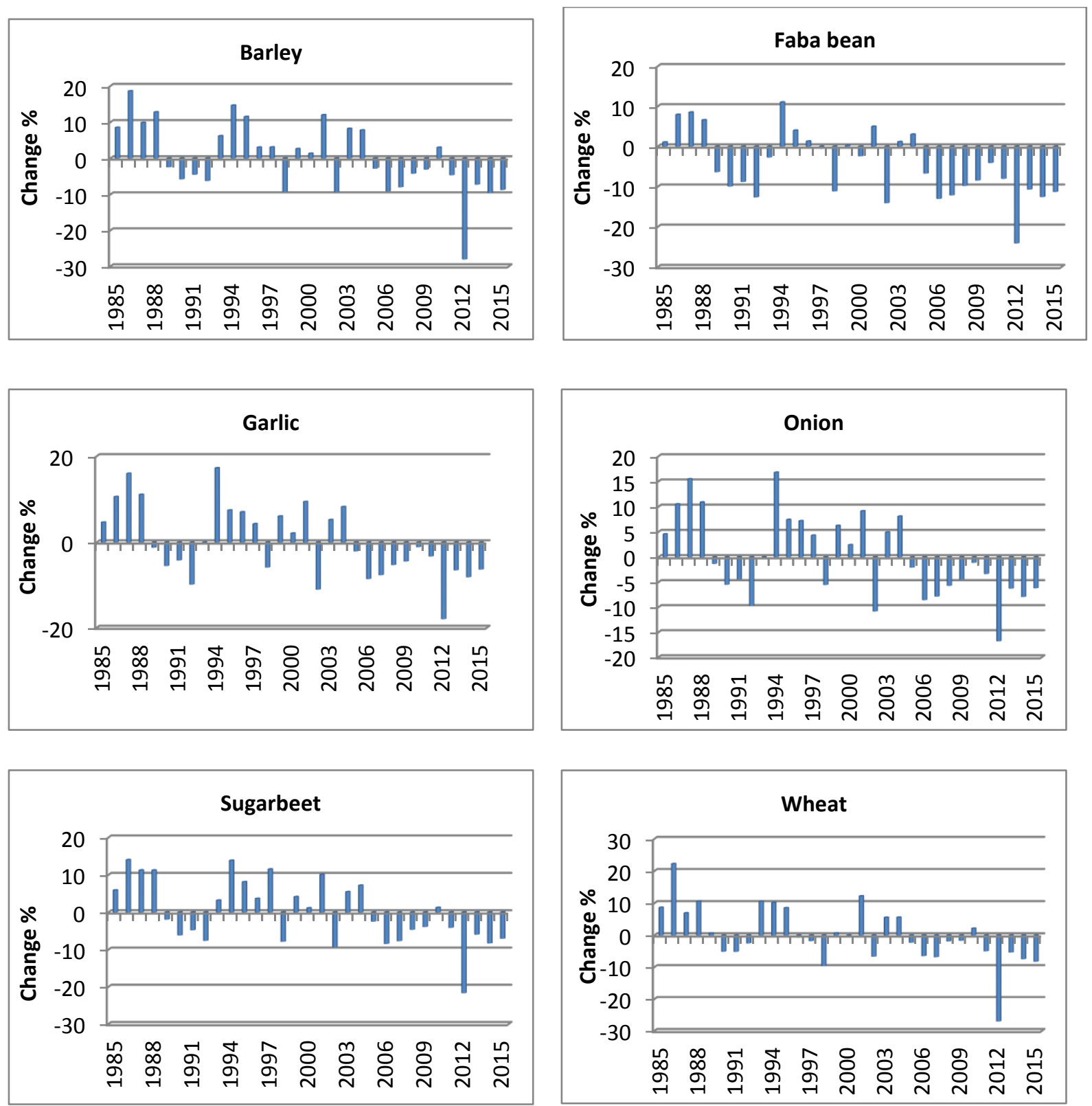

Figure 2: Annual \% change in the amount of irrigation water requirements for winter field crops due to weather variability as compared to the three-decade average

\section{Summer field and vegetable crops}

Summer field crops grown in the study area include cotton, maize, onion, rice, soybean and sugarcane and the summer vegetables are the same as 
those grown in the winter. Figures 4 and 5 show yearly variations from the means, representing impact on climate variability on IWR.
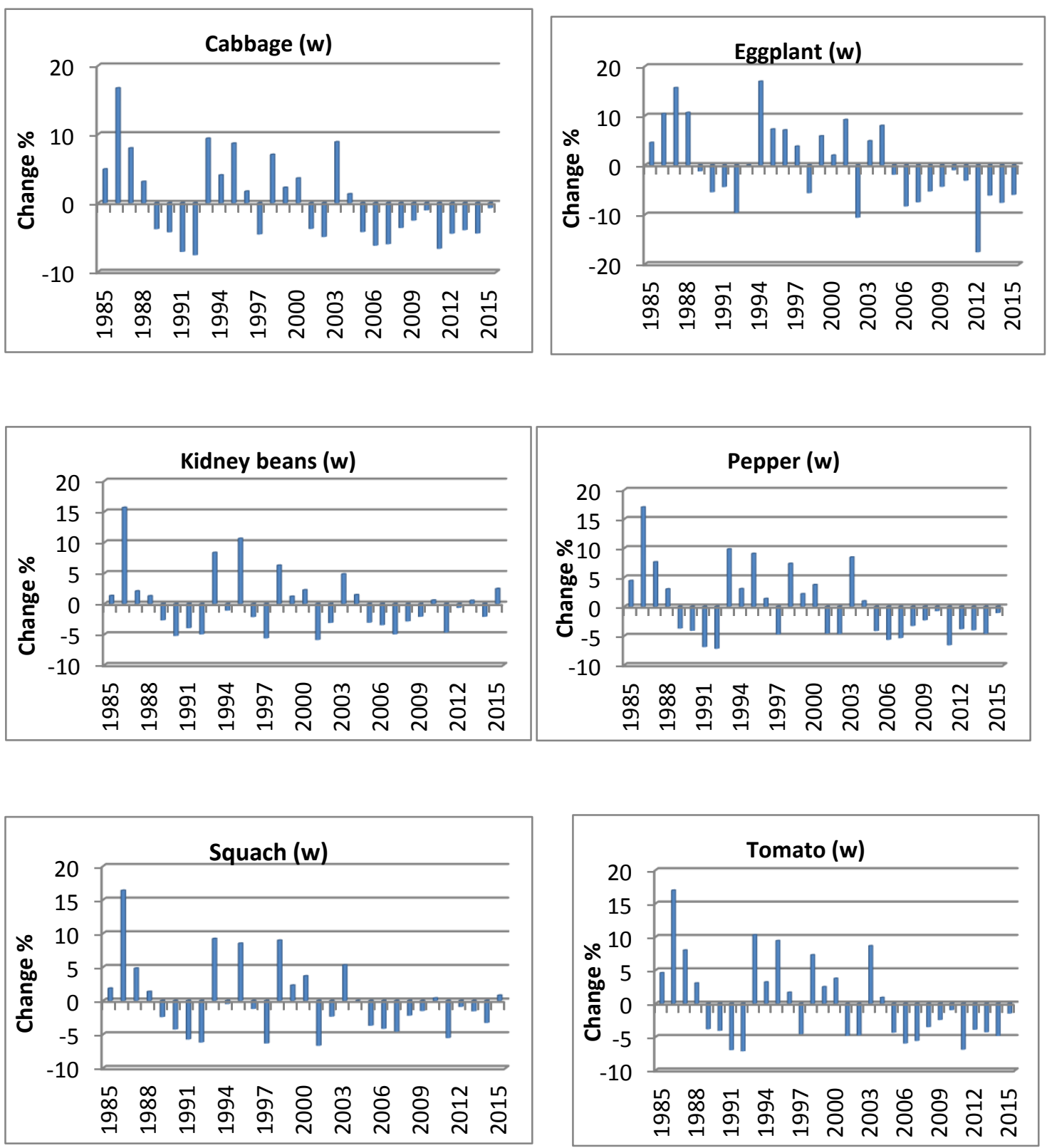

Figure 3: Annual \% change in the amount of irrigation water requirements for winter vegetables due to weather variability as compared to the three-decade average 
Note that Egypt changed from an old variety of rice that had a growing period of 150 days to a new variety of rice with only 120 days growing period during the last ten years in order to save irrigation water. Therefore, two entries for rice are shown in data presented in Figure 4 covering the period 1985 to 2005 and the period 2006 to 2015.

Results indicate that average IWR for summer field crops over the study period were 12966, 9344, 12319, 15746, 11548, 9546 and $25411 \mathrm{~m}^{3} \mathrm{ha}^{-1}$ for cotton, maize, onion, rice (old varieties), rice (new varieties), soybean and sugarcane, respectively. However, the average values for summer vegetables were 10757, 10931, 5483, 10553, 6854 and $11158 \mathrm{~m}^{3} \mathrm{ha}^{-1}$ for cabbage, eggplant, green kidney bean, pepper, squash and tomato, respectively.

The highest variation of IWR compared to the calculated average over the three-decade for summer field crops are observed for sugarcane (from $9 \%$ up to $+19 \%$ ) followed by cotton (from $-7 \%$ up to $+19 \%$ ), while the highest variations for summer vegetables were for squash (from -24\% up to $+20 \%$ ) followed by green kidney bean (from $-20 \%$ to $+20 \%$ ).

Results as shown in Figures 4 and 5 indicate that the lowest IWR were found in 2012 for sugarcane, squash and green kidney bean. This likely related to a decrease in maximum temperature during April and May by 26.8 and $24.3 \%$, and in wind speed by 24.7 and $24.8 \%$, respectively, when compared to the calculated three-decade average. As for cotton crop, the lowest IWR were found during the 2002 season due to a large decrease in wind speed compared to the 3 -decade average. The percent change of wind speed was $-35,-42,-48,-56,-45$ and $-33 \%$ for the months from April up to September.

On the other hand, the highest IWR for sugarcane, cotton and squash are seen in 1986. This increase attributes to an increase in the maximum and minimum temperature and wind speed and to a decrease in relative humidity compared to the three-decade average. The change percentage during the months of February, March and April, are $+8,+5$ and $+7 \%$ for maximum temperature; $+15,+12$ and $+13 \%$ for minimum temperature; $+44,+53$ and $+52 \%$ for wind speed; and $-19,-1$ and $-21 \%$ for relative humidity. Regarding green kidney bean, the highest IWR were found in 1993, due to a large increase in wind speed during the months of March, 
April and May by 67, 45 and 62\%, respectively, compared to the threedecade average in addition to a slight increase in temperature in some months.
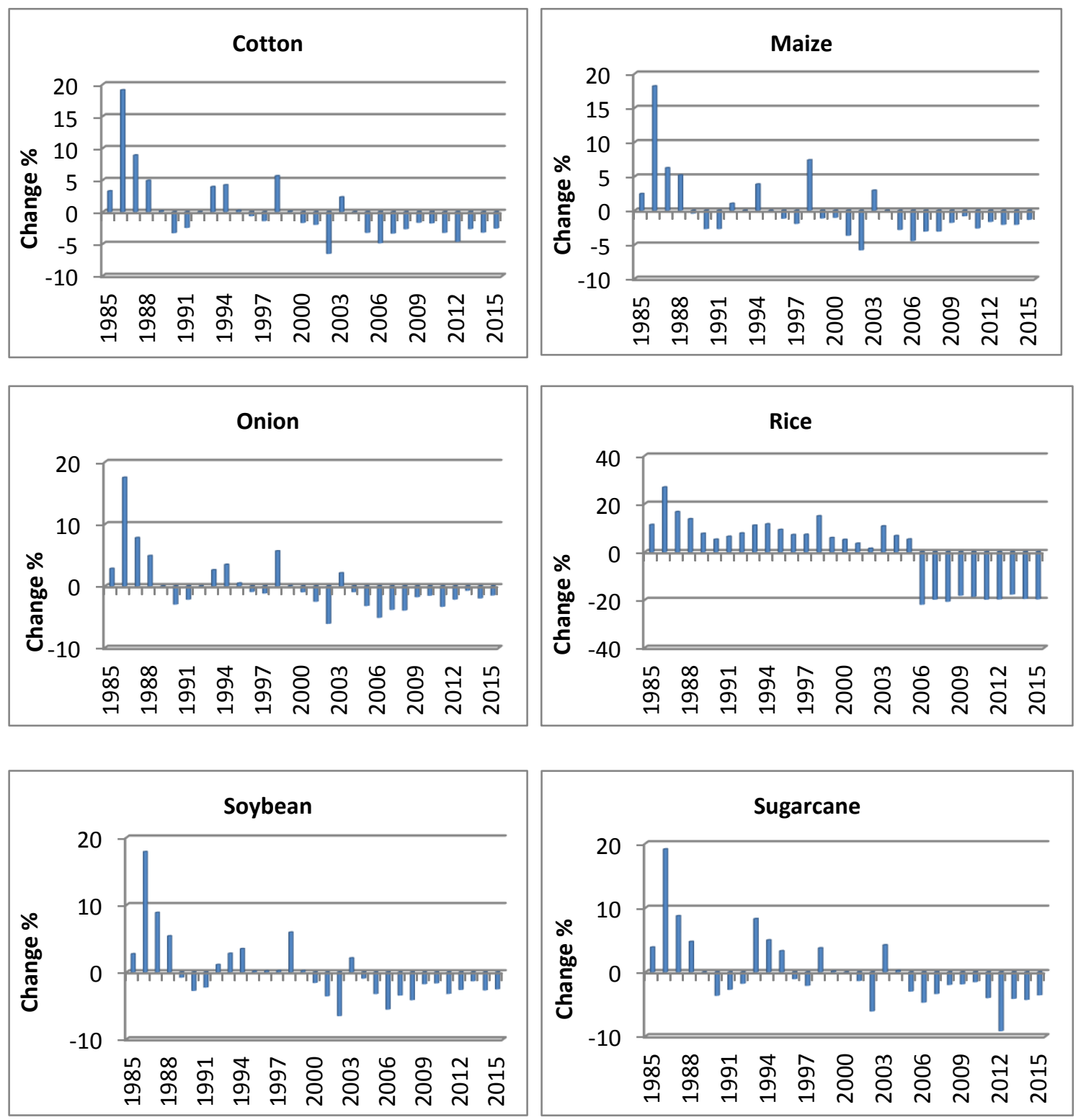

Figure 4: Annual \% change in the amount of irrigation water requirements for summer field crops due to weather variability as compared to three the -decade average 

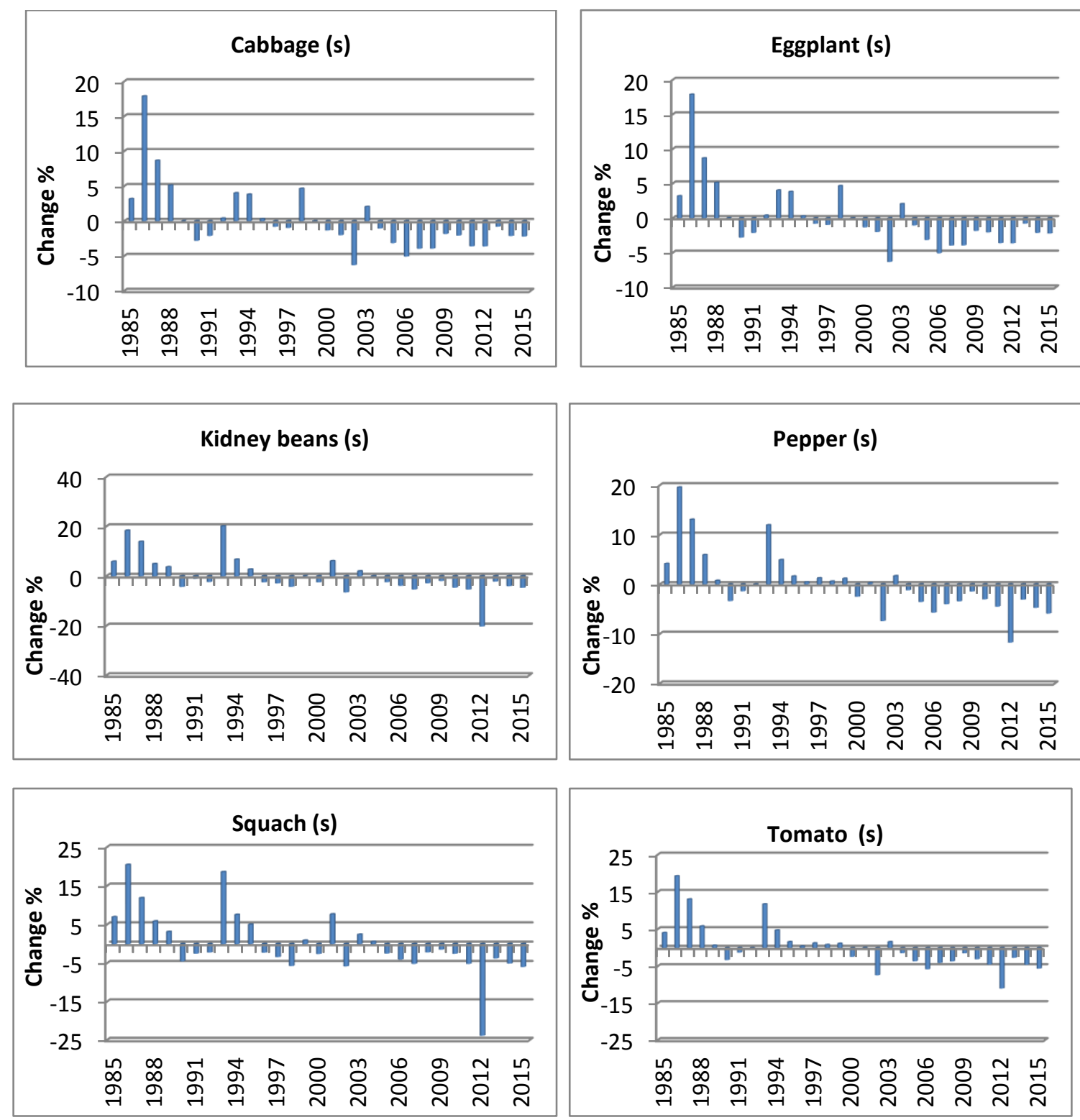

Fig. 5: Annual \% change in the amount of irrigation water requirements

for summer vegetables due to weather variability as compared to the three-decade average

\section{Orchard trees}

Most orchard trees are irrigated year-round, while some orchards have a fasting period during winter. Orchards grown in the study area include apple, banana, grape, mango, olive and orange. Figure 6 presents annual 
average values of variation percentage of IWR during the period 1985 to 2015 , as well as extreme percent deviation from the mean.
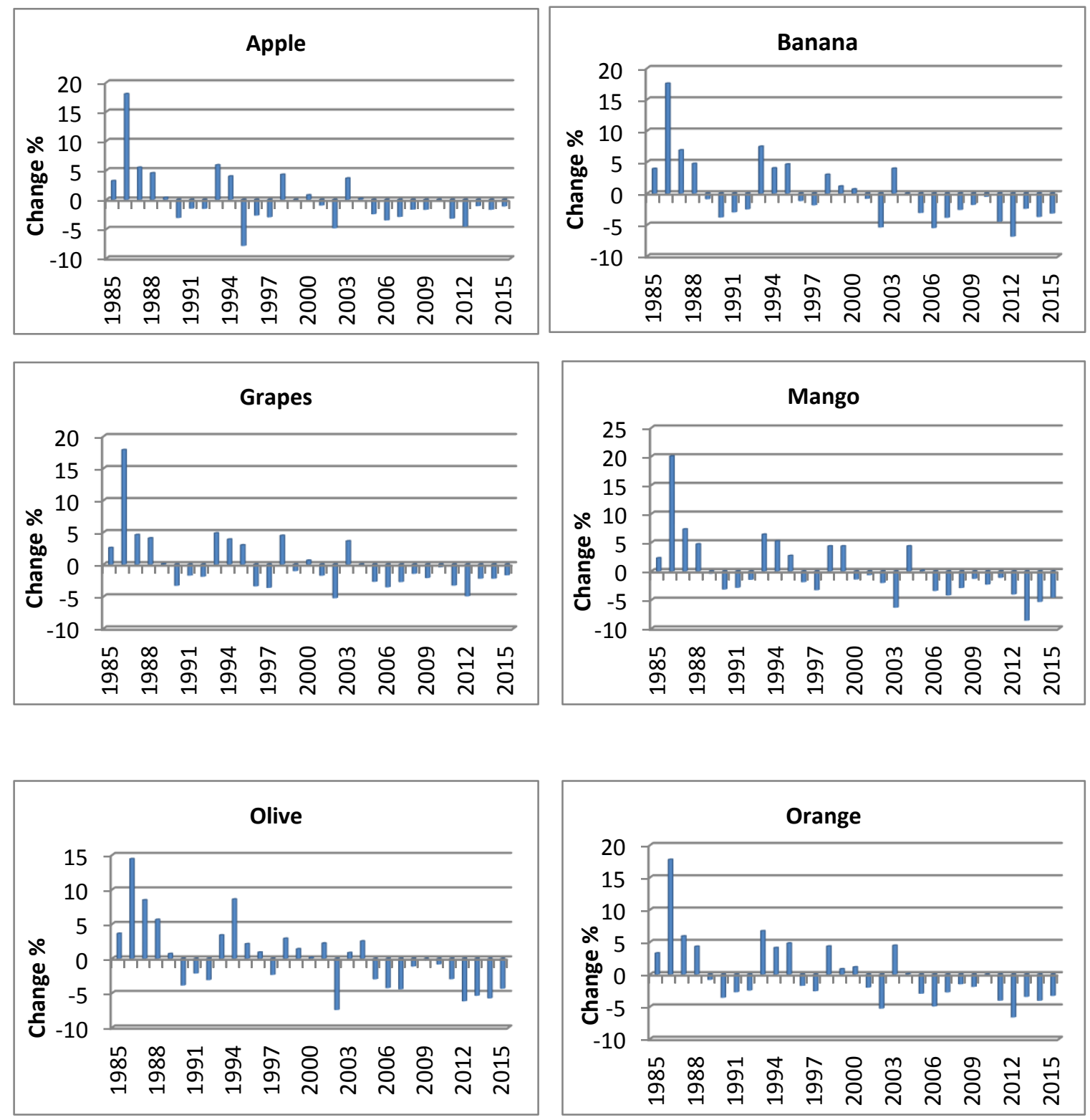

Fig. 6: Annual \% change in the amount of irrigation water requirements for orchards due to weather variability as compared to the three-decade average

The annual $\%$ deviation from the mean for the same period presented in Figure 6. Mean IWR for orchard trees over the study period reached 
14848, 24059, 11728, 19368, 12587 and $16329 \mathrm{~m}^{3} \mathrm{ha}^{-1}$ for apple, banana, grape, mango, olive and orange, respectively.

Weather conditions vary from one year to another (intra annual variability) that led to varying IWR for orchard crops. The IWR values are higher during the years of 1986, 1987, 1988, 1993, 1994 with the highest in 1986 .The IWR values are highest in 1986 with $+18 \%,+18 \%$, $+18 \%,+20 \%,+14 \%$ and $+18 \%$ for apple, banana, grape, mango, olive and orange, respectively.

In contrast, the lowest IWR is in 1995 for Apple, 2002 for olive, 2012 for banana, grape and orange and 2013 for mango. The percentage IWR decrease during these years are $-8 \%,-7 \% \%,-5 \%,-9 \%,-7 \%$ and $-7 \%$ for Apple, banana, grape, mango, olive and orange, respectively.

Lower than mean IWR is noted for orchards during the last five years. These results are consistent with the results of other crops grown in the Northern Nile Delta Region.

\section{Comparison between mean IWR for winter and summer vegetable crops}

These results are helpful guidelines for improving water management in case of a water short year. Result shows that tomato has the highest IWR for a winter and summer vegetable crops with mean values of about 5205 and $11158 \mathrm{~m}^{3} \mathrm{ha}^{-1}$ for the winter and summer season, respectively. The highest difference between summer and winter crops is observed for eggplant ( $145 \%$ increase in summer), while the lowest difference is found for squash ( $41 \%$ increase in summer).

The increase in IWR for winter tomato compared to the other winter vegetables is $8 \%, 17 \%, 37 \%, 2 \%$ and $7 \%$ for cabbage, eggplant, green kidney bean, pepper and squash, respectively. The increase in IWR of summer tomato compared to the same vegetables in summer season is $4 \%, 2 \%, 104 \%, 6 \%$ and $63 \%$, respectively. The main reason for the difference in results between summer season and winter season is the weather, while the main reason for the difference in IWR for vegetable crops in the same season is mainly due length of the growing season. In some cases, the crop coefficient plays an important role in this issue. 
Table 5: Comparison between IW requirements for vegetable crops during summer and winter cultivation

\begin{tabular}{|l|c|c|c|c|}
\hline \multirow{2}{*}{ Crop } & \multicolumn{2}{|c|}{ Average IW } & $\begin{array}{c}\text { Ratio } \\
\text { (summer/winter) }\end{array}$ & $\begin{array}{c}\text { \% increase } \\
\text { in summer }\end{array}$ \\
\cline { 2 - 3 } & Winter & Summer & & 122 \\
\hline Cabbage & 4,839 & 10,757 & 2.22 & 145 \\
\hline Eggplant & 4,459 & 10,931 & 2.45 & 44 \\
\hline Kidney bean & 3,812 & 5,483 & 1.44 & 107 \\
\hline Pepper & 5,086 & 10,553 & 2.07 & 41 \\
\hline Squash & 4,852 & 6,854 & 1.41 & 114 \\
\hline Tomato & 5,205 & 11,158 & 2.14 & \\
\hline
\end{tabular}

\section{CONCLUSIONS}

- This paper aims to calculate the amounts of irrigation water requirements (IWR) for crops grown in the Nile Delta Region during three decades (1985 to 2015) and the variation in IWR from year to year as a result of weather variability. FAO-CROPWAT8.0 model is used to estimate IWR during the study period.

- The mean amount of IWR for winter crops ranged between $3812 \mathrm{~m}^{-}$ ${ }^{3} \mathrm{ha}^{-1}$ (kidney beans) to $5610 \mathrm{~m}^{3} \mathrm{ha}^{-1}$ (sugar beet). On the other hand, IWR for summer crops are much higher with mean values ranging between $5483 \mathrm{~m}^{3} \mathrm{ha}^{-1}$ (kidney beans) to $25411 \mathrm{~m}^{3} \mathrm{ha}^{-1}$ (sugarcane).

- For orchard crops, mean IW requirements ranged between 11728 $\mathrm{m}^{3} \mathrm{ha}^{-1}$ (grapes) to $24059 \mathrm{~m}^{3} \mathrm{ha}^{-1}$ (banana). IWR variations due to weather fall between $-14 \%$ to $+27 \%$ for winter field crops, between $-6 \%$ to $+17 \%$ for winter vegetable crops, between $-6 \%$ and $+19 \%$ for summer field crops, between $-6 \%$ to $+20 \%$ for summer vegetable crops, and between $-5 \%$ and $+20 \%$ for orchards.

- The results show the importance of basing irrigation water application and scheduling on actual weather measurements to minimize water loss or crop stress. Results also show that the cultivation of the same vegetable crops during summer results in an increase in water consumption ranging between 41 to $145 \%$.

- These results may provide guidance for prioritization of water allocation in case of a water shortage condition. 


\section{REFERENCES}

Allam M.N., El Gamal F. and Hesham M. (2005). Irrigation systems performance in Egypt. In: Lamaddalen a N. (ed.), Lebdi F. (ed.), Todorovic M. (ed.), Bogliotti C. (ed.). Irrigation systems performance. Bari: CIHEAM, 2 005. p. 85-9, 8 (Options Méditerranéennes : Série B. Etudes et Recherches; n. 52).

Allen, R. G., Pereira, L. S., Raes, D., and Smith, M. (1998). "Crop evapotranspiration: Guidelines for computing crop requirements." Irrigation and Drainage Paper No. 56, FAO, Rome, Italy.

Dastane, N. G. (1972). A practical manual for water uses research in agriculture. $2^{\text {nd }}$ Ed. Published at Poona by Narabahart Prakashan Peth. Poona-2 India.

Doorenbos, J. and W. O. Pruitt (1977). Guidelines for predicting crop water requirements. Irrigation and Drainage Paper No. 24. Rome, Italy.

El-Marsafawy, S. M., M. A. Ali, A. Y. Salib and H. M. Eid. (1998). Effect of different sowing dates on some wheat varieties yield and their water relations. The Third Conference Meteorology \& Sustainable Development, Feb.15-17, Egypt.

ICARDA report (2016). http://www.icarda.org/capacitydevelopment/integrated-water-and-land-management

Jensen, M. E. (1980). Design and operation of farm irrigation systems. An ASAE Monograph, No. 3 in a series published by Amer. Sec. of Agric. Eng. 2950 Nile Road. P.O. Box 410

Kumar R , Jat MK and Shankar V. (2012). Methods to estimate irrigated reference crop evapotranspiration - a review. Water Sci Technol. 2012; 66(3):525-35. doi: 10.2166/wst.2012.191. https://www.ncbi.nlm.nih.gov/pubmed/22744682

Molden, David, R. Sakthivadivel and Zaigham Habib (2001). Basin-Level Use and Productivity of Water: Examples from South Asia, IWMI Research Report 49, Colombo: International Water Management Institute.

Rayan, A. A.; F. A. Khalil, K. A. Mohamed and S. M. El-Marsafawy (2000). Scheduling irrigation of cotton crop under different nitrogen 
fertilizer levels in Upper Egypt. The 5th Conference Meteorology \& Sustainable Development, Feb. 22-24, Egypt.

Schneekloth J., T. Bauder, N. Hansen (2009). Limited Irrigation

Management: Principles and Practices. Colorado State University, Extension, State of Possibilities.

Sheng-Feng Kuo, Bor-Jang Lin and Horng-Je Shieh (2001). CropWat model to evaluate crop water requirements in Taiwan. International Commission on A25, Irrigation and Drainage 1st Asian Regional Conference Seoul, 2001.

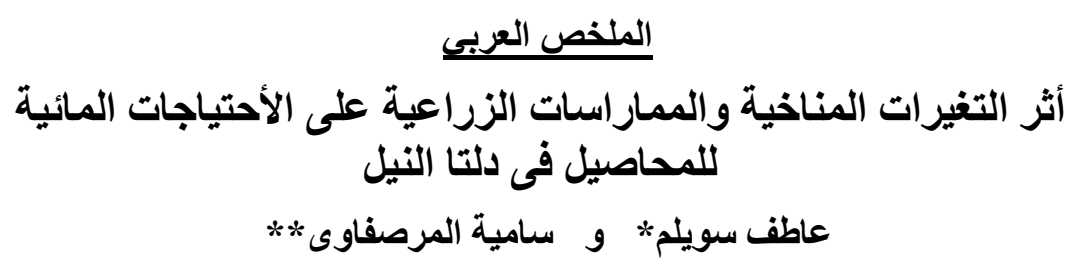

تستهلك الزر اعة في مصر حوالي •^^\% من الموارد المائية المتاحة. مع إستمرار تز ايد الطلب على الإمداد بالمياه رغم الثبات النسبى للمياه المتاحة، يجب ان تستخل المياه المتاحة بأقصى كفاءة

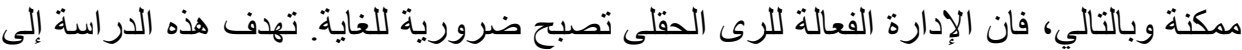
تقدير مدى التغير فى الاحتياجات المائية للرى للمحاصيل المختلفة المنزر عة في منطقه دلتا النيل

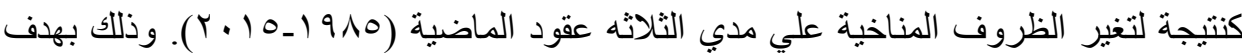

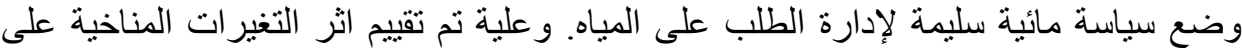

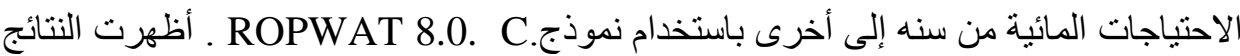

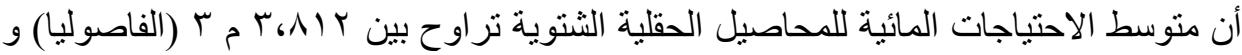
• الحه لبنجر السكر. وكان المتوسط للمحاصيل الحقلية الصيفية هي اعلي من ذلك بكثير مع قيم

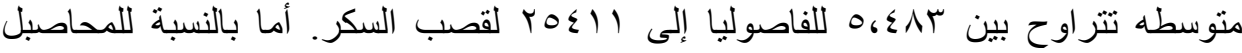

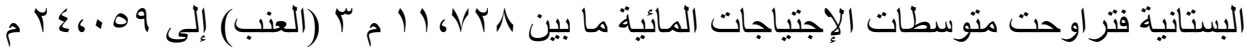

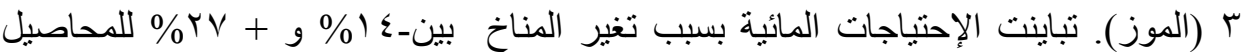

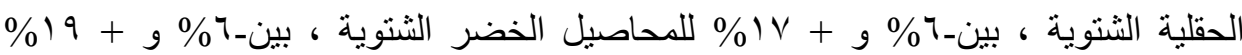

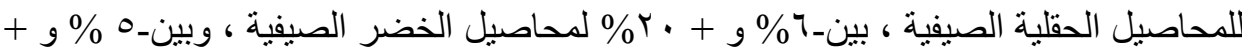

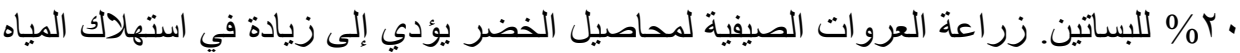

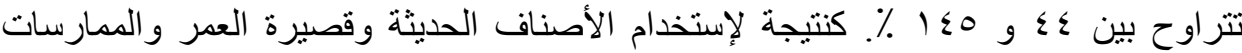

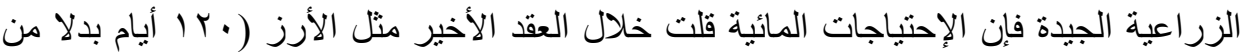

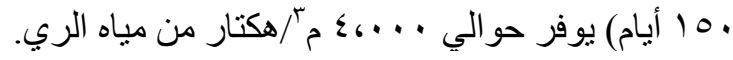

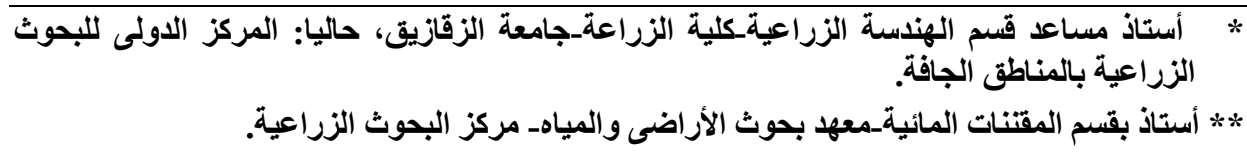

